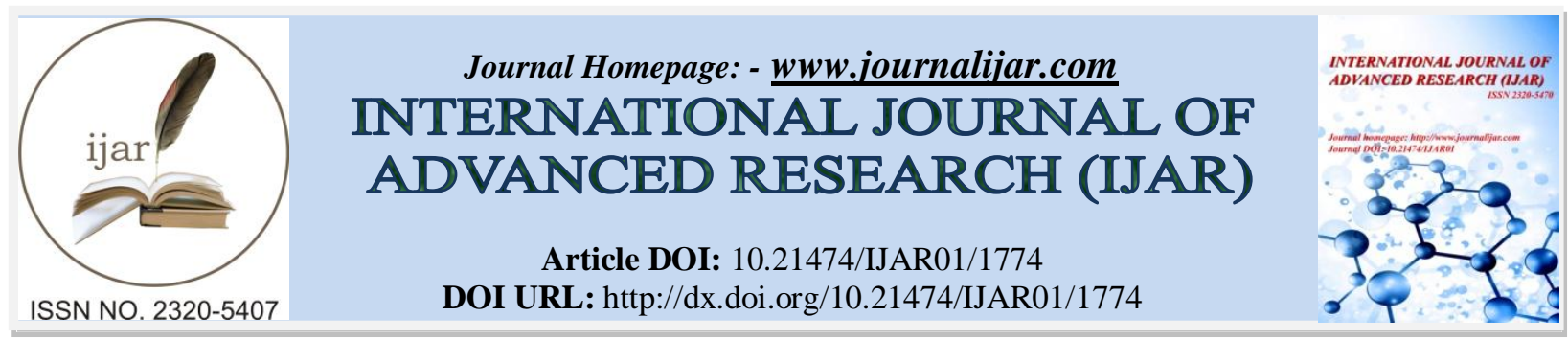

RESEARCH ARTICLE

\title{
PHYTOREMEDIATION OF HEAVY METALS IN URBAN WASTEWATER IRRIGATED SOILS BY USING SELECTED CROP SPECIES IN MYSURU, KARNATAKA, INDIA.
}

*Abhilash M.R ${ }^{1}$, Srikantaswamy $\mathbf{S}^{1,2}$, Shiva Kumar $D^{1}$ and Jagadish $\mathrm{K}^{2}$.

1. Department of Studies in Environmental Science, University of Mysore, Manasagangothri, Mysuru - 570 006, India.

2. Centre for Materials Science and Technology, Vijnana Bhavan, University of Mysore, Manasagangotri, Mysuru -570006 , India.

\section{Manuscript Info}

a......................

Manuscript History

Received: 16 August 2016

Final Accepted: 13 September 2016

Published: October 2016

Key words:-

"Phytoremidiation", "Heavy metal",

"Municipal wastewater", "Bio-

concentration factor", "Translocation

factor", and "Urban wastewater"

\section{Abstract}

Urban cities throughout the word are growing with the population, and producing the unlimited wastewater to environment. Living standards of urban population and industries are contributing in producing more quality of UWW. In the mean time these UWW are not treated properly because of inadequeate technology applied in the treatment of UWW. It is a common practices thouout the world that utilizing UWW are usually contains Heavy metal. In the present study phytoremidiation studies were carryout in the soils which are amended with UWW. The crops which are grown regularly by using UWW in the area. In this study some of the crops were selected for the study Spinach oleracea $L$, Zea mays $L$, Trigonella foenum graecum $L$ these crops are usually consumed by locals citizens for their ingredients in the food preparation., P.purpureum Schumach were used for cattle feed. In the UWW heavy metals are largely presentand they can be remediate by using selected crop species which are artificially irrigated UWW. Phytoremidiation studies by using the selected and locally available crop species used for the study, and it was shows good accumulation ability with low-maintenance. Bio-Concentration Factor (BCF) and Translocation factor (TF) are evident that, crop species performance, apart from practically irrigated crops P.purpureum Schumach is hoard a highest Heavy metals accumulated crop among selected local plants which were grown in the heavy metal contaminated wastewater agricultural fields.

Copy Right, IJAR, 2016,. All rights reserved.

\section{Introduction:-}

Heavy metals are the foremost environmental contaminants and pose a severe risk to human and animal health by their enduring persistence in the environment ${ }^{1}$. Generally, Heavy metal toxicity issues do not arise in natural soils with their native vegetation. Even the soil is naturally high in a particular metal, native plants will often have become adapted over time to the locally elevated levels ${ }^{2}$ However, if humans bring new growth regimes, such as agriculture, with plants not evolved on these specialized soils, then toxicity issues can develop ${ }^{3}$. The remediation of soils contaminated by heavy metals is a cost-rigorous and precisely complex process ${ }^{4,7}$. Inside nastiness of being efficient, these methods are expensive, time consuming and environmentally critical ${ }^{8,9}$. The Plant species differ 
widely in their ability to accumulate heavy metals ${ }^{10}$. Many concluded that concentrations of metals in plants growing in the same soil vary between species and even between genotypes of a species ${ }^{11,12}$. Some of the mechanisms, which may be responsible for plant species differences in metal concentrations, have been identified ${ }^{13}$, Also, the age and the growth stage of the plant can affect the concentration of metals in plants ${ }^{14,15}$. Municipal wastewater usage is a common practice where it flows across the agricultural fields. Wastewater and sewage sludge are used as manure, have also been used by the northern European and Mediterranean civilizations ${ }^{16}$.In the European and North American cities, wastewater will be discharged into the agricultural fields instead of diverting it into the wastewater treatment units to prevent and avoid the water pollution at different levels ${ }^{17}$. Hence, the usage of wastewater has been associated with land application and crop production for centuries ${ }^{18}$. The current physical and chemical remediation technique of heavy metal from contaminated soil-water are expensive, time consuming and environmentally destructive and Soil contaminated with trace metals has become a worldwide problem and pose a serious threat to the environment, leading to losses in agricultural yield and hazardous health effects as they easily enter the food chain. In the research we are selected low-cost and essay maintainable crop species were adopted for effective remediation of heavy metal by selected crop species for saluting to environmental problems.

\section{Materials and methods:-}

The study area of Mysore city is a unique city and was the capital city of former princely state of Karnataka. It has kept alive the royal traditions and spender. Whose growth rate is posed to be that of rapid, equipped with only primary treatment plants, treats only a part of Municipal and Industrial wastewater generated from the city limits. Large quantity of untreated wastewater being discharged into low lying areas and water bodies located in and around the city. Due to the scarcity of water, the untreated wastewater is used for irrigation in the city. The Phytoremidiation studies were carrying out Municipal wastewater contaminated soil. Also, no study is carried Mysore City. In the present study attempts was made to know the behavior of heavy metals in Municipal wastewater contaminated soil, Control soil (Collected in normal agricultural land) and Control crops were collected in normal water irrigated area of Mysuru city to find out tangible phytoremidiation standards and identify efficient local wastewater irrigated crop species for phytoremidiation technique and also, calculate the Translocation factor (TF) ${ }^{19}$, ${ }^{20,21}$ and Bio-Concentration factor ${ }^{22,23}$ of selected Heavy metals and plant species to assess the actual remediation.

Table 1:- Crops grown by using wastewater in Mysuru city

\begin{tabular}{|c|c|}
\hline Name of the Crops grown by using wastewater & Crop sign \\
\hline Spinach oleracea $L$ & \\
\hline Zea mays $L$ & \\
\hline Trigonella foenum graecum $L$ & \\
\hline P.purpureum Schumach & \\
\hline
\end{tabular}

Figure 1:- Land use and crop locality map of Mysuru City

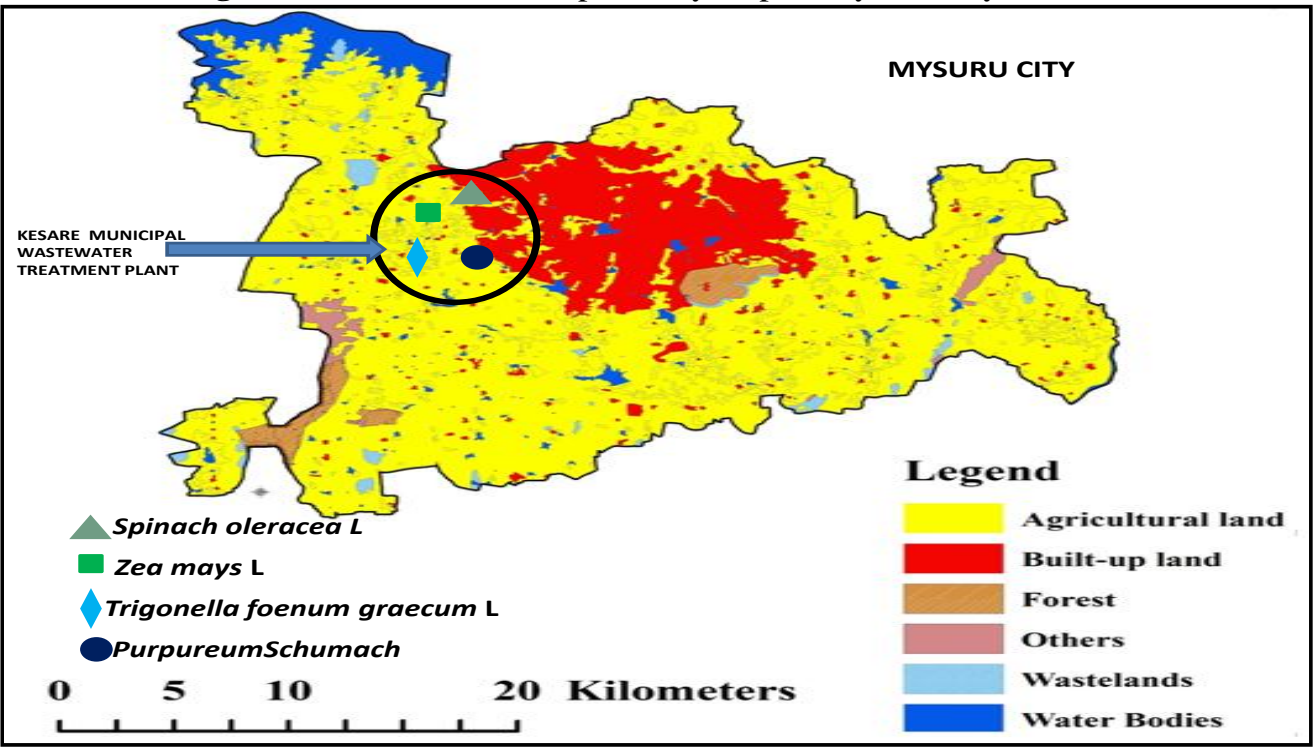




\section{Sampling, Pre-Treatment and Analysis:-}

The soil and plant samples were collected at different points of the Kesare wastewater irrigated zone of Mysuru city, India. The soil and plant samples are collected and dried in sunlight. Soil samples (Root, Stem and Leaves) and plants were dried with the help of oven in the laboratory and then ground in an agate mortar and pestle to pass through a $0.5 \mathrm{~mm}$ stainless steel sieve. Then they were stored in polythene containers at room temperature. The plant samples were analyzed for $\mathrm{pH}$ and digested by using tri acid mixture and $2 \mathrm{ml}$ of aqua-regia has been added to preserve the digested sample and stored in $100 \mathrm{ml}$ distilled container. The digested sample was analyzed for heavy metal concentration by using Inductively Coupled Plasma Atomic Emission Spectroscopy techniques (ICP-AES) using the Perkin-Elmer Optima 8000, ICP-OES.

\section{Results and Discussion:-}

Heavy metal uptake using phytoremidiation technology seems to be a wealthy way to remediate heavy metal contaminated environment. It has been proven to have the most effective approach to assuage the environmental toxic substances associated with contamination, it has some advantages compared with other commonly used conventional technologies, several factors must be considered in order to accomplish a high performance of remediation result. The metal discharging process in to soil environment in Municipal wastewater irrigated areas is a common practice. By the metal mobility and climatic condition together results in metal accumulation in the soil and plant body. In the present study, the evaluation of metal content in both plants and soil were carried out and the results were tabulated in the table 02 to 07 . The analyzed results showed the metal concentration comparatively higher than in the soil environment. Heavy metals can also contaminate the food chain and reduce crop yields. The consumption of plants containing high levels of heavy metals might pose a serious risk to human health. The metal concentration, transfer and accumulation of metals from soil to roots, stem and leaf was evaluated through BCF is an index of the ability of the plant to accumulate a particular heavy metal with respect to its concentration in the soil. Translocation Factor (TF) was described as ratio of heavy metals in plant shoot to that in the plant root. The TF value will be higher for those plants which retain the metal in roots without translocation to aerial parts of the plant body. Present study Spinach oleracea L, Zea mays L, Trigonella foenum graecum L, and P.purpureumSchumach less-expensive and comparatively adjustable crop Varity were used to know the accumulate the heavy metal in Municipal wastewater irrigated soil in 60 days. The concentration of Iron in Municipal wastewater irrigated lands is on the higher rate, because of sewage discharge and corrosion of water supplying pipes from locality. The concentration of Nickel and copper are exceeding the FAO standards due to the improper management of wastewater from industrial in the city. All the examined heavy metal like Copper, Iron, Nickel, Lead and Zinc are shown a superior result in between 40 to 60 respective days time duration with respect to all crops except lead shown below detectable limit in soil.

Table 2:- Heavy metal concentration in Soil and Control Soil

\begin{tabular}{|c|c|c|}
\hline Crop & Heavy metal in Soil & Control (Soil) \\
\hline \multirow{5}{*}{ Spiracia oleracea $L$} & Copper (2.6) & 6.4 \\
\hline & Iron (1738.4) & 311.2 \\
\hline & Nickel (5.8), & 0.4 \\
\hline & Lead (0.5) & 0.5 \\
\hline & Zinc (33.6) & 4.4 \\
\hline \multirow{5}{*}{ Zeamays $L$} & Copper (1.9) & BDL \\
\hline & Iron (1871.9) & 124.1 \\
\hline & Nickel (6.7) & 0.5 \\
\hline & Lead (0.5) & BDL \\
\hline & Zinc (31.4) & 3.1 \\
\hline \multirow{5}{*}{ Trigonella foenum graecum $L$} & Copper $(\mathrm{Cu})(\mathbf{1 . 8})$, & BDL \\
\hline & Iron (1631.8), & 96.8 \\
\hline & Nickel (4.8), & 0.6 \\
\hline & Lead (0.4) & 0.4 \\
\hline & Zinc 25.5), & 4.2 \\
\hline \multirow{5}{*}{ P.Purpurem Schumach } & Copper (32.4) & 2.4 \\
\hline & Iron (1236.1) & 308.8 \\
\hline & Nickel (44.8) & 1.2 \\
\hline & Lead (1.9) & BDL \\
\hline & Zinc (246.6), & 6.5 \\
\hline
\end{tabular}


Table 3:- Heavy metal accumulation in Spiracia oleracea $L$ in plant body and soil ( $\mathrm{mg} / \mathrm{kg})$ in Municipal wastewater irrigated

\begin{tabular}{|c|c|c|c|c|c|c|}
\hline Plant Section & Control & $20^{\text {th }}$ Day & $3^{\text {th }}$ Day & $40^{\text {th }}$ Day & $\begin{array}{c}\text { Total Bio } \\
\text { Concentration }\end{array}$ & Control \\
\hline \multicolumn{7}{|c|}{ Copper } \\
\hline Root & 0.03 & 0.08 & 0.08 & 0.1 & 0.111 & 0.004 \\
\hline Leaf & 0.01 & 0.04 & 0.03 & 0.08 & 0.061 & 0.001 \\
\hline \multicolumn{7}{|c|}{ Iron } \\
\hline Root & 89.5 & 130.7 & 134.2 & 141.8 & 0.285 & 0.287 \\
\hline Leaf & 41.7 & 98.4 & 102.7 & 107.2 & 0.201 & 0.133 \\
\hline \multicolumn{7}{|c|}{ Nickel } \\
\hline Root & 0.1 & 0.4 & 0.7 & 0.8 & 0.344 & 0.25 \\
\hline Leaf & BDL & 0.2 & 0.3 & 0.4 & 0.155 & BDL \\
\hline \multicolumn{7}{|c|}{ Lead } \\
\hline Root & BDL & BDL & 0.2 & 0.2 & 0.8 & BDL \\
\hline Leaf & BDL & BDL & BDL & BDL & BDL & BDL \\
\hline \multicolumn{7}{|c|}{ Zinc } \\
\hline Root & 1.2 & 5.8 & 6.1 & 7.8 & 0.622 & 0.272 \\
\hline Leaf & 0.5 & 0.8 & 0.1 & 1.2 & 0.077 & 0.113 \\
\hline
\end{tabular}

Table 4:- Heavy metal accumulation in Zeamays $L$ in plant body and soil (mg/kg) in Municipal wastewater irrigated area.

\begin{tabular}{|c|c|c|c|c|c|c|}
\hline Plant Section & Control & $20^{\text {th }}$ Day & $3^{\text {th }}$ Day & $40^{\text {th }}$ Day & $\begin{array}{c}\text { Total Bio } \\
\text { Concentration }\end{array}$ & Control \\
\hline \multicolumn{7}{|c|}{ Copper } \\
\hline Root & BDL & 0.1 & 0.3 & 0.1 & 0.263 & BDL \\
\hline Leaf & BDL & 0.08 & 0.09 & 0.09 & 0.136 & BDL \\
\hline \multicolumn{7}{|c|}{ Iron } \\
\hline Root & 40.1 & 171.1 & 172.4 & 182.9 & 1.131 & 0.323 \\
\hline Leaf & 22.2 & 96.1 & 96.9 & 99.2 & 0.107 & 0.178 \\
\hline \multicolumn{7}{|c|}{ Nickel } \\
\hline Root & 0.2 & 0.6 & 0.6 & 0.9 & 0.343 & 0.4 \\
\hline Leaf & 0.1 & 0.2 & 0.2 & 0.2 & 0.104 & 0.2 \\
\hline \multicolumn{7}{|c|}{ Lead } \\
\hline Root & BDL & BDL & 0.1 & 0.1 & 0.4 & BDL \\
\hline Leaf & BDL & BDL & BDL & BDL & BDL & BDL \\
\hline \multicolumn{7}{|c|}{ Zinc } \\
\hline Root & 1.2 & 6.1 & 7.8 & 7.9 & 23 & 0.387 \\
\hline Leaf & BDL & 2.1 & 2.5 & 3.1 & 0.245 & BDL \\
\hline
\end{tabular}

Table 5:- Heavy metal accumulation in Trigonella foenum graecum $L$ in plant body and soil (mg/kg) in Municipal wastewater

\begin{tabular}{|c|c|c|c|c|c|c|}
\hline Plant Section & Control & $\mathbf{2 0}^{\text {th }}$ Day & $3^{\text {th }}$ Day & $\mathbf{4 0}^{\text {th }}$ Day & $\begin{array}{c}\text { Total Bio } \\
\text { Concentration } \\
\end{array}$ & Control \\
\hline \multicolumn{7}{|c|}{ Copper } \\
\hline Root & BDL & 0.3 & 0.5 & 0.9 & 0.944 & BDL \\
\hline Leaf & BDL & BDL & BDL & 0.2 & 0.111 & BDL \\
\hline \multicolumn{7}{|c|}{ Iron } \\
\hline Root & 31.7 & 91.1 & 92.5 & 95.4 & 0.190 & 0.327 \\
\hline Leaf & 8.8 & 16.3 & 25.3 & 27.7 & 0.047 & 0.090 \\
\hline \multicolumn{7}{|c|}{ Nickel } \\
\hline Root & 0.2 & 0.8 & 1.1 & 1.4 & 0.729 & 0.333 \\
\hline Leaf & BDL & 0.2 & 0.2 & 0.3 & 0.145 & BDL \\
\hline \multicolumn{7}{|c|}{ Lead } \\
\hline Root & BDL & BDL & BDL & 1.0 & 2.5 & BDL \\
\hline Leaf & BDL & BDL & BDL & BDL & BDL & BDL \\
\hline \multicolumn{7}{|c|}{ Zinc } \\
\hline Root & 1.7 & 7.8 & 8.0 & 9.8 & 1.070 & 0.404 \\
\hline Leaf & BDL & BDL & BDL & 4.2 & 0.164 & BDL \\
\hline
\end{tabular}


Table 5:- Heavy metal accumulation in P.Purpurem Schumach in plant body and soil (mg/kg) in Municipal

\begin{tabular}{|c|c|c|c|c|c|c|}
\hline $\begin{array}{l}\text { Plant } \\
\text { Section }\end{array}$ & Control & $20^{\text {th }}$ Day & $30^{\text {th }}$ Day & $40^{\text {th }}$ Day & $\begin{array}{c}\text { Total Bio } \\
\text { Concentration }\end{array}$ & Control \\
\hline \multicolumn{7}{|c|}{ Copper } \\
\hline Root & 0.5 & 4.6 & 5.2 & 5.9 & 0.5 & 0.208 \\
\hline Leaf & 0.6 & 2.4 & 2.7 & 2.9 & 0.265 & 0.25 \\
\hline \multicolumn{7}{|c|}{ Iron } \\
\hline Root & 108.3 & 376.2 & 398.7 & 408.9 & 1.045 & 0.350 \\
\hline Leaf & 65.7 & 109.7 & 117.4 & 128.3 & 0.340 & 0.212 \\
\hline \multicolumn{7}{|c|}{ Nickel } \\
\hline Root & 0.5 & 3.7 & 3.9 & 3.9 & 0.267 & 0.416 \\
\hline Leaf & BDL & 1.2 & 1.2 & 1.2 & 0.080 & BDL \\
\hline \multicolumn{7}{|c|}{ Lead } \\
\hline Root & BDL & 1.0 & 2.0 & 2.0 & 2.631 & BDL \\
\hline Leaf & 1.0 & 0.526 & BDL & BDL & BDL & BDL \\
\hline \multicolumn{7}{|c|}{ Zinc } \\
\hline Root & 2.2 & 38.1 & 39.3 & 40.0 & 0.484 & 0.338 \\
\hline Leaf & 0.8 & 8.4 & 9.8 & 10.5 & 0.119 & 0.123 \\
\hline
\end{tabular}

Table 6:- Heavy metal Bio-accumulation in factor in plant body $(\mathrm{mg} / \mathrm{kg})$ in Municipal wastewater.

\begin{tabular}{|c|c|c|c|c|c|c|}
\hline Heavy Metal & Crop & Root & Stem & Leaf & $\begin{array}{c}\text { Total Bio } \\
\text { Accumulation }\end{array}$ & Control \\
\hline \multicolumn{7}{|c|}{ Copper } \\
\hline \multirow{4}{*}{ Copper } & Spiracia oleracea $L$ & 0.111 & 0.050 & 0.061 & 0.195 & 0.007 \\
\hline & Zeamays $L$ & 0.253 & 0.110 & 0.136 & 0.610 & BDL \\
\hline & T. foenum graecum $L$ & 0.944 & 0.333 & 0.111 & 0.738 & BDL \\
\hline & P.Purpurem Schumach & 0.5 & 0.351 & 0.265 & 1.114 & 0.875 \\
\hline \multicolumn{7}{|c|}{ Iron } \\
\hline \multirow{4}{*}{ Iron } & Spiracia oleracea $L$ & 0.285 & 0.227 & 0.201 & 0.713 & 0.615 \\
\hline & Zeamays $L$ & 1.131 & 0.231 & 0.167 & 0.702 & 0.755 \\
\hline & T. foenum graecum $L$ & 0.190 & 0.084 & 0.047 & 0.322 & 0.579 \\
\hline & P.Purpurem Schumach & 1.045 & 0.845 & 0.340 & 2.230 & 0.882 \\
\hline \multicolumn{7}{|c|}{ Nickel } \\
\hline \multirow{4}{*}{ Nickel } & Spiracia oleracea $L$ & 0.344 & 0.189 & 0.155 & 0.070 & 0.25 \\
\hline & Zeamays $L$ & 0.343 & 0.268 & 0.104 & 0.125 & 0.8 \\
\hline & T. foenum graecum $L$ & 0.729 & 0.229 & 0.145 & 0.860 & 0.666 \\
\hline & P.Purpurem Schumach & 0.267 & 0.198 & 0.080 & 0.546 & 0.416 \\
\hline \multicolumn{7}{|c|}{ Lead } \\
\hline \multirow{4}{*}{ Lead } & Spiracia oleracea L & 0.8 & BDL & $\mathrm{BDL}$ & 0.8 & BDL \\
\hline & Zeamays $L$ & 0.4 & BDL & BDL & 0.4 & BDL \\
\hline & T. foenum graecum $L$ & 2.5 & BDL & $\mathrm{BDL}$ & 2.5 & BDL \\
\hline & P.Purpurem Schumach & 2.631 & 1.578 & 0.526 & 4.736 & BDL \\
\hline \multicolumn{7}{|c|}{ Zinc } \\
\hline \multirow{4}{*}{ Zinc } & Spiracia oleracea $L$ & 0.622 & 0.348 & 0.073 & 10.047 & 0.568 \\
\hline & Zeamays $L$ & 2.3 & 0.522 & 0.245 & 1.5 & 0.645 \\
\hline & T. foenum graecum $L$ & 1.070 & 0.674 & 0.164 & 1.909 & 0.595 \\
\hline & P.Purpurem Schumach & 0.484 & 0.290 & 0.119 & 0.894 & 0.753 \\
\hline
\end{tabular}


Table 7:- Heavy metal Translocation factor in factor in plant body ( $\mathrm{mg} / \mathrm{kg}$ ) in Municipal wastewater (Overall average)

\begin{tabular}{|c|c|c|}
\hline Crop & $\begin{array}{c}\text { Translocation } \\
\text { Factor }\end{array}$ & Control \\
\hline \multicolumn{3}{|c|}{ Copper } \\
\hline Spiracia oleracea $L$ & 1.819 & 3.000 \\
\hline Zeamays $L$ & 1.933 & BDL \\
\hline Trigonella foenum graecum $L$ & 8.504 & BDL \\
\hline P.Purpurem Schumach & 1.886 & 0.833 \\
\hline \multicolumn{3}{|c|}{ Iron } \\
\hline Spiracia oleracea $L$ & 1.417 & 2.146 \\
\hline Zeamays $L$ & 6.766 & 1.806 \\
\hline Trigonella foenum graecum $L$ & 4.042 & 3.602 \\
\hline P.Purpurem Schumach & 3.073 & 1.648 \\
\hline \multicolumn{3}{|c|}{ Nickel } \\
\hline Spiracia oleracea $L$ & 0.8 & BDL \\
\hline Zeamays $L$ & 0.4 & BDL \\
\hline Trigonella foenum graecum $L$ & 2.5 & BDL \\
\hline P.Purpurem Schumach & 5.1 & BDL \\
\hline \multicolumn{3}{|c|}{ Lead } \\
\hline Spiracia oleracea $L$ & 0.8 & BDL \\
\hline Zeamays $L$ & 0.4 & BDL \\
\hline Trigonella foenum graecum $L$ & 2.5 & BDL \\
\hline P.Purpurem Schumach & 5.1 & BDL \\
\hline \multicolumn{3}{|l|}{ 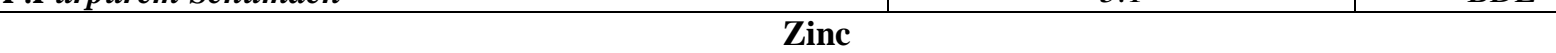 } \\
\hline Spiracia oleracea $L$ & 8.077 & 2.4 \\
\hline Zeamays $L$ & 93.87 & 1.2 \\
\hline Trigonella foenum graecum $L$ & 6.524 & 1.7 \\
\hline P.Purpurem Schumach & 4.067 & 2.75 \\
\hline
\end{tabular}

Note: All the heavy metals expressed in $\mathrm{mg} / \mathrm{kg}, \mathrm{BDL}=$ Below Detectable limit

\section{Conclusion:-}

Mortally consumed larger volume of water; it results with the discharging of wastewater to further treatment is difficult. To meet the short falls of water scarcity, the wastewater should be neither recycled nor it should be reused for irrigation process. The heavy metal input through anthropogenic activities increases the total contents of the trace metals, which may result in the increase of potential environmental risk. Phytoremidiation is the use of living plants to clean-up pollution in the environment like metal contaminants in the soil. The study was conducted to screen plants growing on a contaminated site to determine their potential for metal accumulation. According to the above mentioned criteria, Both $\mathrm{BF}$ and $\mathrm{TF}$ values more than one, indicated that some of the measured heavy metals in plants show good results and they are good accumulator. In the same manner, during the study period, we have come across the determination of phytoremidiation studies in municipal wastewater in the agricultural fields. Four crop species have been identified during the study period and the P.purpureumSchumach is considered as highest heavy metals accumulated crop among the entire crop species were examined grown in the Municipal wastewater irrigated agricultural fields. P.purpureumSchumach > Trigonella foenum graecum > Zeamays L > and Spiracia oleracea $L$ species significantly accumulate the heavy metal because of having the higher mobility for all heavy metals in wastewaters and soil in between 40 to 60 days time duration. The BCF and TF study identifies the mobility and bio-accumulation rates of the trace metals among the different fraction with consecutive information. Finally, the crop species are the promising agents to accumulator of heavy metals in normal environmental conditions with fewer expenses and effective agents for heavy metal infectivity troubles. 


\section{References:-}

1. Subhashini, V. and Swamy, A.V.V.S. (2013) Phytoremediation of $\mathrm{Pb}$ and Ni Contaminated Soils Using Catharanthusroseus (L.). Universal Journal of Environmental Research and Technology, 3, 465-472.

2. Ouzounidou, G., Symeonidis, L., Babalonas, D. and Karataglis, S. (1994), Comparative responses of a coppertolerant and a copper-sensitive population of Minuartiahirsuta to copper toxicity. J.Plant Physiology, 144, 109115.

3. Fergus, I.F. (1954), Manganese toxicity in an acid soil. Queens land Journal of Agricultural Science. 11, $15-21$.

4. Barcelo, J. and Poschenrieder, C. (2003) Phytoremediation: Principles and Perspectives. Contributions to Science, 2, 333-334.

5. Xu, M. and Lu, N. (2012) Research on Removing Heavy Metals From Mine Tailings. Disaster Advances, 5, 116-120.

6. Montinaro, S., Concas, A., Pisu, M. and Cao, G. (2012) Remediation of Heavy Metals Contaminated Soils by Ball Milling. Chemical Engineering Transactions, 28, 187-192.

7. Jadia, C.D. and Fulekar, M.H. (2009) Phytoremediation of Heavy Metals: Recent Techniques. African Journal of Biotechnology, 8, 921-928.

8. Danh, L.T., Truong, P., Mammucari, R., Tran, T. and Foster, N. (2009) Vetiver Grass, Vetiveria zizanioides: A Choice Plant for Phytoremediation of Heavy Metals and Organic Wastes. International Journal of Phytoremediation, 11, 664-691. http://dx.doi.org/10.1080/15226510902787302

9. Ahmadpour, P., Ahmadpour, F., Mahmud, T.M.M., Abdu, A., Soleimani, M. and Hosseini Tayefeh, F. (2012) Phytoremediation of Heavy Metals: A Green Technology. African Journal of Biotechnology, 11, 14036-14043.

10. Nouri, J., Khorasani, N., Lorestani, B., Karami, M., Hassani, A.H. and Yousefi, N. (2009) Accumulation of Heavy Metals in Soil and Uptake by Plant Species with Phytoremediation Potential. Environmental Earth Sciences, 59, 315- 323. http://dx.doi.org/10.1007/s12665-009-0028-2

11. Kabata-Pendias, A. and Pendias, H. (2001) Trace Elements in Soils and Plants. 3rd Edition, CRC Press, Boca Raton, 403 p.

12. Hamon, R.E., Wundke, J., McLaughlin, M.J. and Naidu, R. (1997) Availability of Zinc and Cadmium to Different Plant Species. Australian Journal of Soil Research, 35, 1267-1277. http://dx.doi.org/10.1071/S97052

13. Hamon, R. and McLaughlin, M. (2003) Food Crop Edibility on the Ok Tedi/Fly River Flood Plain. Report for OK, 66p.

14. Elekes, C.C. (2014) Eco-Technological Solutions for the Remediation of Polluted Soil and Heavy Metal Recovery. In: Hernández-Soriano, M.C., Ed., Environmental Risk Assessment of Soil Contamination, InTech, Rijeka, 309-335.http://dx.doi.org/10.5772/57314

15. Nouri, J., Khorasani, N., Lorestani, B., Karami, M., Hassani, A.H. and Yousefi, N. (2009) Accumulation of Heavy Metals in Soil and Uptake by Plant Species with Phytoremediation Potential. Environmental Earth Sciences, 59, 315- 323. http://dx.doi.org/10.1007/s12665-009-0028-2

16. Jiménez, B. and Asano, T. (2008) Water Reclamation and Reuse around the World. In: Jiménez, B. and Asano, T., Eds., Water Reuse: An International Survey of Current Practice, Issues and Needs, IWA Publishing, London, 648.

17. Keraita, B.N., Jiménez, B. and Drechsel, P. (2008) Extent and Implications of Agricultural Reuse of Untreated, Partly Treated and Diluted Wastewater in Developing Countries. CAB Reviews: Perspectives in Agriculture, Veterinary Science, Nutrition and Natural Resources, L3, 1-15. http://dx.doi.org/10.1079/PAVSNNR20083058

18. Rattan, R.K., Datta, S.P., Chhonkar, P.K., Suribabu, K. and Singh, A.K. (2005) Long-Term Impact of Irrigation with Sewage Effluent on Heavy Metal Content in Soils, Crops and Groundwater-A Case Study. Agriculture, Ecosystems \& Environment, 109, 310-322.

19. Baker AJM, Brooks RR (1989) Terrestrials higher plants which hyper accumulate metallic elements. A review of their distribution, ecology and phytochemistry. Biorecovery 1: 81- 26.

20. Zhang WH, Cai Y, Tu C, Ma QL (2002) Arsenic speciation and distribution in an arsenic hyperaccumulating plant. Sci Environ 300: 167-177.

21. Fayiga AQ, Ma LQ (2006) Using phosphate rock to immobilize metals in soils and increase arsenic uptake in Pteris vittata. Sci Total Environ 359: 17-25.

22. Ma LQ, Komar KM, Tu C, Zhang W, Cai Y, Kenelly ED (2001) A fern that hyper accumulates arsenic. Nature 409: 579-582.

23. Cluis C (2004) Junk-greedy greens: phytoremediation as a new option for soil decontamination. Biotech J 2: $60-67$. 